\title{
Spent espresso coffee grounds as a source of anti-proliferative and antioxidant compounds
}

\author{
Michele Balzano ${ }^{\mathrm{a}}$, Monica R. Loizzo ${ }^{\mathrm{b}, *}$, Rosa Tundis ${ }^{\mathrm{b}}$, Paolo Lucci ${ }^{\mathrm{c}}$, Oscar Nunez ${ }^{\mathrm{d}, \mathrm{e}, \mathrm{f}}$, \\ Dennis Fiorini $^{g}$, Alessandra Giardinieri ${ }^{\mathrm{a}}$, Natale G. Frega ${ }^{\mathrm{a}}$, Deborah Pacetti ${ }^{\mathrm{a}}$ \\ a Dipartimento di Scienze Agrarie, Alimentari e Ambientali, Università Politecnica delle Marche, Via Brecce Bianche, 60131 Ancona, Italy \\ ${ }^{\mathrm{b}}$ Department of Pharmacy, Health and Nutritional Sciences, University of Calabria, 87036 Rende (CS), Italy \\ ${ }^{\mathrm{c}}$ Department of Agri-Food, Animal and Environmental Sciences, University of Udine, via Sondrio 2/a, 33100 Udine, Italy \\ ${ }^{\mathrm{d}}$ Department of Chemical Engineering and Analytical Chemistry, University of Barcelona, Spain \\ ${ }^{\mathrm{e}}$ Research Institute of Food Nutrition and Food Safety, University of Barcelona, Spain \\ ${ }^{\mathrm{f}}$ Serra Hunter Fellow, Generalitat de Catalunya, Barcelona, Spain \\ ${ }^{\mathrm{g}}$ School of Science and Technology, Chemistry Division, University of Camerino, V. S. Agostino 1, I-62032 Camerino, MC, Italy
}

\section{A R T I C L E I N F O}

\section{Keywords:}

Coffee by-products

Polyphenols

Tocopherols

Tyrosol

Antioxidant properties

Anti-proliferative activity

\begin{abstract}
A B S T R A C T
Disposal of spent espresso coffee grounds (SCG) is costly and leads to the loss of bioactive compounds that could be fractionated, in several applications. This work aimed to investigate phenolic profile, tocopherols, and antioxidant and anti-proliferative activities of SCGs ethanolic extracts from coffee powders differing in coffee provenience and composition (arabica/robusta). Tyrosol, detected for the first time in SCGs, was the most abundant phenolic measured (121-1084 mg/kg in the extract), along with 4-hydroxybenzoic acid and vanillin (885-1813 and 340-1103 mg/kg, respectively). Extract derived from 100\% robusta from Guatemala (S7-R) showed the highest $\alpha$ - to $\beta$-tocopherol ratio of 1.2 and the highest antioxidant potential as evidenced by RACI and GAS values of -0.43 and 0.20 , respectively. Moreover, S7-R showed a promising anti-proliferative activity toward human lung carcinoma cells (A549), with $\mathrm{IC}_{50}$ value of $61.2 \mu \mathrm{g} / \mathrm{mL}$ comparable to that given by the positive control vinblastine ( $\mathrm{IC}_{50}$ value of $67.3 \mu \mathrm{g} / \mathrm{mL}$ ).
\end{abstract}

\section{Introduction}

Coffee is one of the world's most widely consumed beverages. World coffee consumption is estimated at 9714 million of $\mathrm{kg}$ in year 2017/18, $1.8 \%$ higher than previous year (2016/17). Colombia, Vietnam, Indonesia, Ethiopia and Brazil are the major producers while Europe is responsible for the highest consumption (one-third of total coffee worldwide consumption) (Brazilian Association of Coffee Industry Associação Brasileira da Indústria de Café (ABIC), 2019). Recently, the coffee-producing nations are also increasing their domestic consumption. China, Panama, Kenya, Senegal and United States are considered the highest potential markets in the coming years (International Coffee Organization, 2018).

The coffee industry has a significant impact on the environment, producing $>2$ billion tons of coffee by-products (bio-waste) annually. These by-products are generated by the treatment and processing of coffee cherries, the roasting of green coffee beans and the coffeebrewing preparation. Due to the high organic load and the presence of compounds such as caffeine, tannins, and polyphenols, coffee by-products can have negative effects on the environment. Thus, their disposal needs to be properly managed. Following the policies introduced by European Commission for food waste management (Directive 2008/98/ EC, 2008; EU Publication (2012), innovative research is expected to improve the management of food by product resources and open new markets in novel functional foods.

In this scenario, great attention has been devoted to find ways of reducing spent coffee grounds (SCGs) environmental impact and/or transforming them into added-value products. SCGs consist in solid residues left after the production of coffee beverages and instant coffee. Annually, the worldwide production of SCGs are accountable for about 6 million tons (Getachew \& Chun, 2017). A total of 50\% of SCGs come from the industrial preparation of instant soluble coffee and the remaining 50\% come from the worldwide production of different coffee brews in cafeterias, restaurants and homes (Getachew \& Chun, 2017). SCGs are characterized by fine particle size, high organic load and moisture content. The composition of SCGs includes an oil fraction

\footnotetext{
* Corresponding author at: Department of Pharmacy, Health and Nutritional Sciences, University of Calabria, 87036 Rende (CS), Italy.

E-mail address: monica_rosa.loizzo@unical.it (M.R. Loizzo).
} 
Table 1

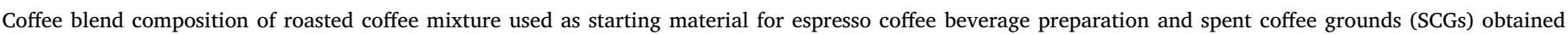
samples.

\begin{tabular}{|c|c|}
\hline Composition of starting coffee blend & Spent Coffee grounds (sample code) \\
\hline $100 \%$ Arabica from Puerto Rico & S1-A \\
\hline $100 \%$ Arabica from Colombia & S2-A \\
\hline $100 \%$ Arabica (50\% from Brazil, $20 \%$ from Colombia, $20 \%$ from Guatemala, $10 \%$ from Ethiopia) & S3-A \\
\hline $\begin{array}{l}40 \% \text { Robusta ( } 15 \% \text { from Vietnam, } 25 \% \text { from India) } / 60 \% \text { Arabica ( } 20 \% \text { from Brazil, } 20 \% \text { from Colombia, } 10 \% \text { from Guatemala, } 10 \% \\
\text { from Costa Rica) }\end{array}$ & $\mathrm{S} 4-\mathrm{A}_{60} \mathrm{R}_{40}$ \\
\hline 90\% Robusta (20\% from India, 70\% from Vietnam) / 10\% Arabica (from Brazil) & $\mathrm{S} 5-\mathrm{A}_{10} \mathrm{R}_{90}$ \\
\hline 75\% Arabica (Unknown)/25\% Robusta (Unknown) _ Decaffeinated coffee blend _ & S6- $\mathrm{A}_{75} \mathrm{R}_{25}$ \\
\hline $100 \%$ Robusta from Guatemala & S7-R \\
\hline
\end{tabular}

(7.9-26.4\%), crude fiber (19.7-22.1\%), and several bioactive compounds (caffeine, trigonelline, phenolics, minerals, lignin, and melanoidins) (Cruz et al., 2012; Monente, Ludwig, Irigoyen, De Peña, \& Cid, 2015). Due to their functional properties (i.e., water-holding capacity, oil-holding capacity, and emulsifying activity), raw SCGs have been applied as biosorbents and as fillers and additives for polymer composites (Moustafa et al., 2017). Many works have also investigated the possibility to reutilize raw SCGs as soil fertilizers, due the slow release of nitrogen in the soil, and as supplements in animal feed (Cruz et al., 2012). However, the high caffeine, tannin, and chlorogenic acid amounts found in SCGs result are toxic to plants and soil microorganisms and confer unpleasant taste to animal feeds (Janissen \& Huynh, 2018).

In light of this, although direct utilization of raw SCGs can be seen as one of the economically advantageous paths, fractionation of SCGs may enlarge their applicability. Fractionation of SCGs allows secondary uses of the oil fraction, phenolic compounds, and carbohydrates, as well as remaining residual materials. Carbohydrates and crude fiber isolated from SCGs are a good substrate for fermentation technology (Ramalakshmi, Rao, Takano-Ishikawa, \& Goto, 2009). SCGs oil has been also applied in biotechnological production of ethanol (Al-Hamamre, Foerster, Hartmann, Kröger, \& Kaltschmitt, 2012).

The extraction of antioxidant compounds from SCGs would allow the recovery of bioactive compounds useful for the food industry. SCGs polyphenol-rich extracts are exploited in food manufacturing as shelflife enhancers, stabilizers and for food fortification. Several authors (Campos-Vega, Loarca-Pina, Vergara, \& Oomah, 2015; Monente et al., 2015) reported that phenolic compounds, caffeine and melanoidins found in espresso SCGs water extract are able to act as antimicrobical agents for extend food shelf-life, mainly acting against Gram-positive bacteria and yeast. Kim, Ahn, Eun, and Moon (2016) evaluated the antioxidant effect of SCGs ethanol and water extracts in oil and raw/ cooked meat system. Ethanolic extract was effective in preventing lipid oxidation in oil emulsion and raw meat systems, but was not effective enough to prevent oxidative changes in cooked-meat packaged in oxygen permeable bags for $>3$ days.

Jiménez-Zamora, Pastoriza, and Rufián-Henares (2015) evaluated the in vitro antimicrobial, prebiotic and antioxidant activity of SCGs extracts and their melanoidins fraction. Authors underlined that coffee melanoidins interfere with the prebiotic activity of SCGs. On the contrary, SCG-coffee melanoidins fraction exerts an intense antimicrobial activity that could inhibit the growth of pathogenic bacteria in food products. In addition, SCGs and SCG-coffee melanoidins were highly antioxidant. More recently, Iriondo-DeHond et al. (2019) reported the chemical profile and the antioxidant activity of coffee by-products obtained before and after the roasting (husk and parchment, and silverskin, respectively) and suggest the use of these by-products as healthy food ingredients.

In this context, the present study was aimed to investigate the chemical and biological properties of ethanolic extract from SCGs deriving from the preparation of espresso coffee. In order to evaluate the potential application of SCGs extracts as suitable ingredient in formulations of nutraceutical/functional foods, we have screened the ethanolic extracts for their polar phenolic substances content and composition, $\alpha$ - and $\beta$-tocopherol content, antioxidant and anti-proliferative activities. Taking into account that the presence of bioactive compounds in espresso SCGs, as well as in espresso beverage, could depend on the coffee variety of the starting material, and different espresso SCGs samples obtained from different coffee blend mixtures (arabica and robusta) but with the same conditions for brewing process, were investigated. In this way, differences in terms of composition and bioactivity among the SCGs samples could be determined, highlighting the compositional variation presented by espresso SGCs.

\section{Materials and methods}

\subsection{Chemicals and reagents}

All chemicals and reagents used in this study were purchased from Sigma-Aldrich Chemical Co. Ltd. (Milan, Italy) and VWR International (Milan, Italy) and, unless specified otherwise, were analytical grade or higher. Water (resistivity above $18 \mathrm{M} \Omega * \mathrm{~cm}$ ) was obtained from a MilliQ SP Reagent Water System (Millipore, Bedford, MA, USA). All the solvents and solutions were filtered through a $0.45 \mu \mathrm{m}$ PTFE filter from Supelco (Bellefonte, PA, USA) before use. Cell culture and cell culture materials were obtained from Sigma-Aldrich (Milan, Italy).

\subsection{Preparation of espresso coffee and collection of SCG samples}

The roasted coffee beans from Coffea arabica and C. canephora var. robusta and roasted coffee blends were supplied by a local industrial coffee roaster (Caffè del Faro, Robin S.r.l., Montegranaro, Italy). Arabica coffees were from Puerto Rico, Colombia, Brazil, Guatemala, Costa Rica and Ethiopia while robusta coffee beans were from India, Vietnam and Guatemala (Table 1). Three $100 \%$ arabica coffee samples, two coffee blends with different arabica/robusta ratio, one $100 \%$ robusta coffee sample and one decaffeinated coffee blend sample were selected. Coffee samples were collected during two different crop years in order to reduce the differences correlated to the harvest year and to the blending lots. All coffee mixtures were roasted at $175^{\circ} \mathrm{C}$ for $15 \mathrm{~min}$.

The espresso coffees were prepared by using a coffee machine VA388 Black Eagle Gravitech (Victoria Arduino, Italy). The grinding was performed by using a grinder machine K30 Mahlkönig (Hemro Manufacturing, Germany $\mathrm{GmbH})$. Ground coffee $(7 \mathrm{~g})$ was inserted in a 1-cup filter holder, water temperature was $92{ }^{\circ} \mathrm{C}$ and pressure, $9 \mathrm{~atm}$. The total collected coffee volume was $20 \mathrm{~mL}$. For each coffee sample, the brew preparation was repeated in triplicate.

\subsection{Preparation of the SCG ethanolic extract}

After the brew preparation, the obtained SCGs were dehydrated at $65{ }^{\circ} \mathrm{C}$ for $12 \mathrm{~h}$ and extracted by maceration. Briefly, $7 \mathrm{~g}$ of dried SCG and $30 \mathrm{~mL}$ of anhydrous ethanol were transferred into glass flasks and the mixture magnetically stirred in the dark, at $25^{\circ} \mathrm{C}$ for $12 \mathrm{~h}$. Then, the 
top phase was filtered through Whatman filter paper \#4 (9.0-cm diameter) and the collected solution was dried in a rotary evaporator.

\subsection{Ultra-high performance liquid chromatography - fluorescence (UHPLC- FLD) analysis of tocopherols}

The tocopherols profile of the ethanolic extracts was determined following the procedure reported by Giardinieri et al. (2019). Briefly, ethanolic extract $(30 \mathrm{mg}$ ) was dissolved in $5 \mathrm{~mL}$ of acetonitrile and UHPLC-FLD separation was performed on Ascentis ${ }^{\circledR}$ Express C18, $(75 \times 4.6 \mathrm{~mm}, 2.7 \mu \mathrm{m}$, from Supelco). The mobile phase was acetonitrile/methanol $(90: 10, v / v)$, at a flow rate of $0.45 \mathrm{~mL} / \mathrm{min}$. The injection volume was $1 \mu \mathrm{l}$. FLD was set with an excitation wavelength of $290 \mathrm{~nm}$ and an emission wavelength of $330 \mathrm{~nm}$. For the quantification, seven standard stock solutions of each tocopherol in acetonitrile were prepared in the range $25-250.0 \mu \mathrm{g} / \mathrm{mL}$ and analyzed to obtain the calibration curve (correlation coefficients $\mathrm{R}^{2}=0.996-0.999$ ).

\subsection{Ultra-high performance liquid chromatography (UHPLC) - high- resolution mass spectrometry (HRMS) determination of phenolic compounds}

UHPLC-HRMS analysis of ethanolic extracts were carried out using an Accela UHPLC system (Thermo Fisher Scientific, San Jose, CA, USA) equipped with a quaternary pump following the procedure reported by Loizzo et al. (2019). Briefly, Ascentis Express C18 $(150 \times 2.1 \mathrm{~mm}$, $2,7 \mu \mathrm{m}$ ) (Supelco, Milan, Italy) column was employed. The mobile phase was a mixture of solvent A $(0.1 \%$ formic acid in water) and solvent B ( $0.1 \%$ formic acid in acetonitrile) and the flow rate was $300 \mu \mathrm{L} / \mathrm{min}$. Gradient elution program: from 0 to $1 \mathrm{~min}, 10 \% \mathrm{~B}$; 1-20 min, linear gradient from 10 to $95 \% \mathrm{~B} ; 20-23 \mathrm{~min}$, isocratic step at $95 \% \mathrm{~B}$; $23-25 \mathrm{~min}$, back to initial conditions at $10 \% \mathrm{~B}$, and 25-30 min, isocratic step at $10 \%$ B for column re-equilibration. The UHPLC system was coupled to a Q-Exactive quadrupole-Orbitrap (Thermo Fisher Scientific) mass spectrometer equipped with a heated electrospray probe ionization source (H-ESI II). HESI-II was operated in negative ionization mode. Nitrogen was used as a sheath gas, sweep gas and auxiliary gas at flow rates of 60, 0 and 10 a.u. (arbitrary units), respectively. Heater temperature was set at $350{ }^{\circ} \mathrm{C}$. Capillary temperature was set at $320{ }^{\circ} \mathrm{C}$ and electrospray voltage at $-2.5 \mathrm{kV}$. The HRMS instrument was operated in full MS scan with a $m / z$ range from 100 to 1500 , and the mass resolution tuned into 70,000 full-width halfmaximum (FWHM) at $m / z 200$, with an automatic gain control (AGC) target (the number of ions to fill C-Trap) of 5.0E5 with a maximum injection time (IT) of $200 \mathrm{~ms}$. Thirty-five polyphenols were targeted, eighteen of which were detected and/or quantified in the samples, as discussed in Section 3.3. Polyphenols that were not detected were: gallic acid, 2,5-dihycroxybenzoic acid, resveratrol, ellagic acid, homogentisic acid, sinapic acid, morin hydrate, ursolic acid, rutin hydrate, quercetin, myricetin, polydatin, trans-cinnamic acid, asiatic acid, genkwanin, rosmanol and rosmarinic acid. Identification and confirmation criteria based on chromatographic retention time, accurate mass measurements (with errors lower than $5 \mathrm{ppm}$ ), and isotopic pattern match, as well as comparison with product ion scan spectra were employed.

\subsection{Antioxidant activity}

\subsubsection{Radical scavenging assays}

Radical scavenging activity of SCGs ethanolic extracts was investigated by using two different spectrophotometric methods namely 2,2-diphenyl-1-picrylhydrazyl (DPPH) and 2,2'-azino-bis(3-ethylbenzothiazoline-6-sulphonic acid (ABTS) test (Loizzo et al., 2012, 2019). Results of DPPH radical scavenging activity was expressed as follow: scavenging activity $=\left[\left(A_{0}-A_{1} / A_{0}\right) \times 100\right]$, where $A_{0}$ is the absorbance of the blank, and $A_{1}$ is the absorbance in the presence of the spent coffee extract.

For the ABTS test a solution of $\mathrm{ABTS}^{+}$and potassium persulphate was prepared. After $12 \mathrm{~h}$ the solution was diluted with anhydrous ethanol until an absorbance measure of 0.70 at $734 \mathrm{~nm}$ by using Perkin Elmer 40 UV-VIS spectrophotometer (Milan, Italy). The spent coffee extract and diluted $\mathrm{ABTS}^{+}$solution were mixed and after 5 min the absorbance was read. The $\mathrm{ABTS}^{+}$scavenging ability was calculated as follow: scavenging activity $=\left[\left(\mathrm{A}_{0}-\mathrm{A}\right) /\left(\mathrm{A}_{0}\right)\right] \times 100$, where $\mathrm{A}_{0}$ is the absorbance of the control reaction and $A$ is the absorbance in the presence of spent coffee extract. Ascorbic acid was used as control in both assays and $\mathrm{IC}_{50}$ values are reported in Table 5.

\subsection{2. $\beta$-Carotene bleaching test}

The protection of SCGs ethanol extracts on lipid peroxidation was assessed as previously described (Loizzo et al., 2019). Briefly, $1 \mathrm{~mL}$ of $\beta$ carotene (2.5 mg in $5 \mathrm{~mL}$ of chloroform) was mixed with linoleic acid $(20 \mu \mathrm{L})$ and $100 \%$ Tween $20(200 \mu \mathrm{L})$. The absorbance was measured at $470 \mathrm{~nm}$ against a blank at $t=0$ and successively after $30 \mathrm{~min}$ incubation. Propyl gallate was used as control and IC $_{50}$ value is reported in Table 5.

\subsubsection{Ferric reducing ability power (FRAP) assay}

The FRAP assay was applied following the procedure previously described by Loizzo et al. (2019). The FRAP value represents the ratio between the slope of the linear plot for reducing $\mathrm{Fe}^{3+}$-TPTZ reagent by SCG extracts compared to the slope of the plot for $\mathrm{FeSO}_{4}$. Butylated hydroxytoluene (BHT) was used as positive control and tested at concentration of $2.5 \mathrm{mg} / \mathrm{mL}$ (Table 5 ).

\subsubsection{Relative antioxidant capacity index (RACI)}

Standard scores derived from different antioxidant assays (ABTS, DPPH, $\beta$-carotene bleaching test, FRAP) were used to calculate the Relative Antioxidant Capacity Index (RACI) (Loizzo et al., 2019). This statistical application integrates the antioxidant capacity values generated from different in vitro methods and provides a ranking of antioxidant activity of different samples. The standard score is calculated by using the following equation:

()

where $\mathrm{x}$ is the raw data, $\mu$ is the mean, and $\sigma$ is the standard deviation.

\subsubsection{Global antioxidant score (GAS)}

T-scores was used to calculate the value of Global Antioxidant Score (GAS) following the equation:

$\mathrm{T}-$ score $=(\mathrm{X}-\min ) /(\max -\min )$

where min and max, respectively, represent the smallest and largest values of variable $\mathrm{X}$ among the investigated extract (Loizzo et al., 2019).

\subsection{Cell culture}

Seven cancer cell lines, adenocarcinomic human alveolar basal epithelial cells A549 (ECACC No. 86012804), human caucasian breast carcinoma (MCF-7, ECACC $\mathrm{N}^{\circ}: 86012803$ ), human cervix epitheloid carcinoma (HeLa, ECACC $\mathrm{N}^{\circ}$ :93021013), human caucasian breast adenocarcinoma (MDA-MB-231, ECACC $\mathrm{N}^{\circ}$ :92020424), human amelanotic melanoma (C32, ATCC $\mathrm{N}^{\circ}$ :CRL-1585), human caucasian prostate carcinoma (LNCaP, ECACC $\mathrm{N}^{\circ}: 891102011$ ) and human caucasian prostate adenocarcinoma (PC3, ECACC $\mathrm{N}^{\circ}$ : 90112714) were used in our investigation. All media, buffers, trypsin and dyes were filter-sterilized prior to use and warmed to $37^{\circ} \mathrm{C}$. The MCF-7, HeLa, A549 and PC3 cells were cultured in Dulbecco's Modified Eagle Medium (DMEM) medium while MDA-MB-231, C32, and LNCaP cells were cultured in Roswell Park Memorial Institute (RPMI) 1640 medium. Both media were supplemented with $1 \%$ L-glutamine, $1 \%$ penicillin/streptomycin and $10 \%$ fetal bovine serum. The cell lines were maintained at $37{ }^{\circ} \mathrm{C}$ in a $5 \% \mathrm{CO}_{2}$ 
atmosphere with 95\% humidity. The cultures were passed once a week by trypsinization using trypsin-EDTA solution (1:30). Cells counts and viability were performed using a standard trypan blue cell counting technique.

\subsubsection{Sulforhodamine B (SRB) assay}

The anti-proliferative activity of SCGs ethanol extracts was performed by using the protein-staining sulforhodamine B (SRB) assay as previously described (Lucci, Pacetti, Loizzo, \& Frega, 2015). Cells were trypsinized, counted and placed in 96-well plates at optimal plating density. This cell density was chosen for each cell line to ensure exponential growth throughout the experimental time and to ensure a linear relationship between absorbance evaluated at $490 \mathrm{~nm}$ and cell number. In particular, $5 \times 10^{4}$ cells were plated for MCF-7 and C32, $8 \times 10^{4}$ cells for HeLa and MDA-MB-231, $15 \times 10^{4}$ cells for LNCaP and $15 \times 10^{4}$ for A549 and PC3. After 24 h the cells were treated with different concentrations of SCGs ethanol extracts (5-200 $\mu \mathrm{g} / \mathrm{mL})$. After $48 \mathrm{~h}$ of exposure, $100 \mu \mathrm{L}$ of ice-cold $40 \%$ trichloroacetic acid (TCA) was added to each well, left at $4{ }^{\circ} \mathrm{C}$ for $1 \mathrm{~h}$, and washed with distilled water. The TCA-fixed cells were stained for 30 min with $50 \mu \mathrm{L}$ of $0.4 \%(w / v)$ SRB in $1 \%$ acetic acid. Plates were washed with $1 \%$ acetic acid and air dried overnight. For reading plate, the bound dye was solubilised with $100 \mu \mathrm{L}$ of $10 \mathrm{mM}$ tris base [tris(hydroxymethyl)aminomethane]. The absorbance was read by using a Molecular Devices SpectraMax Plus Plate Reader (Molecular Devices, Celbio, Milan, Italy) at $490 \mathrm{~nm}$. Cell survival was measured as the percentage absorbance compared to the untreated control. Vinblastine sulphate salt and doxorubicin were used as positive controls and $\mathrm{IC}_{50}$ values are reported in Table 6.

\subsection{Statistical analysis}

All experiments were carried out in triplicate. Data were expressed as means \pm standard deviation (S.D.). The dose-response curve was obtained by plotting the percentage inhibition versus concentration. The inhibitory concentration $50 \%\left(\mathrm{IC}_{50}\right)$ was calculated by non-linear regression with the use of Prism Graph Pad version 4.0 for Windows (Graph Pad Software, San Diego, CA, USA).

Differences of the analyzed compounds (tocopherols, polyphenols) among SCG samples were calculated using one way analysis of variance (ANOVA) with Tukey's post hoc procedure, with a level of significance at $p<0.05$ (R Project for Statistical Computing; $\mathrm{R}$ Foundation for Statistical Computing, Wien, Austria). Differences in terms of antioxidant and anti-proliferative activity within and between groups were evaluated by one-way ANOVA followed by a multicomparison Dunnett's test $(\alpha=0.01):{ }^{* * * *} p<0.0001,{ }^{* * *} p<0.001 * * p<0.01$ compared to the positive controls. Pearson's correlation coefficient $(r)$ and linear regression, assessment of repeatability, calculation of average and relative standard deviation were performed using Microsoft Excel 2010 software.

\section{Results and discussion}

\subsection{Extraction yield}

Samples from arabica coffee mixtures provided higher ethanol extraction yield in comparison to robusta variety samples (Table 2). SCG ethanolic extract amount ranged from 5.8 to $11.2 \mathrm{~g} / 100 \mathrm{~g}$ of dry powder, where the lowest value was found for the sample S7-R $(100 \%$ robusta) and the highest for S3-A (100\% arabica). Extraction yields were lower as compared to values reported by Page, Arruda, and Freitas (2017) for ethanol extract from espresso (capsule) spent coffee grounds dry waste $(20.8 \mathrm{~g} / 100 \mathrm{~g})$ largely due to the different extraction conditions: a cold extraction was performed in our study $\left(25{ }^{\circ} \mathrm{C}\right.$ for $\left.12 \mathrm{~h}\right)$ and a warm extraction process $\left(60^{\circ} \mathrm{C}\right.$ for $30 \mathrm{~min}$ ) in the study of Page et al. (2017). The designation of samples is reported in Table 1.

\subsection{Tocopherol content}

Tocopherols are bioactive compounds able to inhibit lipid oxidation in foods and biological systems.

Coffee beans are rich in tocopherols, but no literature has investigated the tocopherol profile of SCGs. Consequently, our work examined the presence of tocopherols in espresso SCGs. $\alpha$-Tocopherol and ß-tocopherol predominated in all SCG samples. Our results were consistent with the data reported for roasted coffee beans, where the total amount of tocopherols in the Arabica varieties is almost three times higher than in the robusta varieties. The predominant tocopherol is $\beta$ tocopherol in both coffee varieties. However, the concentration of $\beta$ tocopherol in relation to the $\alpha$-tocopherol is almost three times in Arabica, while it is nearly one in robusta (Górnaś et al., 2014). It has been reported that $\alpha$-tocopherol content in Arabica roasted beans ranges between 2.4 and $6.9 \mathrm{mg} / 100 \mathrm{~g}$ of dry bean whereas it accounts for $0.3-4.9 \mathrm{mg} / 100 \mathrm{~g}$ in dry robusta beans. The $\beta$-tocopherol content has been reported to range between 1.6 and $21.3 \mathrm{mg} / 100 \mathrm{~g}$ in dry Arabica beans and between 1.6 and $7.5 \mathrm{mg} / 100 \mathrm{~g}$ in dry robusta beans (Alves, Casal, Alves, \& Oliveira, 2009).

In the present study, a wide range of concentration in the SCGs between 299 and $1508 \mathrm{mg} / \mathrm{Kg}$ (Table 2) for the total $\alpha$ - and $\beta$-tocopherol was found with a ratio $\alpha$-tocopherol/ $\beta$-tocopherol from 0.4 to 1.2. This makes SCGs extracts a valuable source of tocopherols, especially for $\beta$-tocopherol, if considering that the typical sources, i.e. vegetable oils, contain much lower (Shaidi, 2000) or comparable amount; e.g., wheat germ oil, one of the richest sources of $\beta$-tocopherol, has been reported to contain $106.5 \mathrm{mg} / 100 \mathrm{~g}$ of $\beta$-tocopherol (Woollard \& Indyk, 2003).

S2-A (100\% arabica from Colombia) resulted significantly richer $(p<0.05)$ in $\alpha$ and $\beta$-tocopherol than all the other samples.

The lowest $\alpha$ and $\beta$-tocopherol amounts were found in the sample in S7-R (100\% robusta from Guatemala). Referring the values to the dry spent powder, the total tocopherol content ranged between $1.7 \mathrm{mg} /$ $100 \mathrm{~g}$ in S7-R and $13.2 \mathrm{mg} / 100 \mathrm{~g}$ in S2-A. Higher $\beta$-tocopherol levels are found in $100 \%$ arabica samples, with significant differences $(p<0.05)$ as compared to blend and to $100 \%$ robusta samples.

\subsection{Polyphenol profile of espresso SCG ethanol extracts}

Since the total polyphenol content of roasted coffee is mainly represented by phenolic acids, and more specifically hydroxycinnamic acids (caffeic, chlorogenic, coumaric, ferulic and sinapic acids), most of the literature focused on the investigation of these compounds in spent coffee grounds.

Especially chlorogenic acids and their related compounds (i.e. caffeoylquinic, feruloylquinic and $p$-coumaroylquinic acids) were deeply investigated in the past. However, during coffee processing, including roasting and brewing preparation, the formation of other phenolic compounds with antioxidant activity (i.e. Maillard reaction products, cholorogenic acid degradation products) can be promoted (Alongi \& Anese, 2018). Thus, in the present paper a detailed identification of the phenolic constituents of SCGs ethanolic extracts was carried out by means of UHPLC-HRMS analysis. As reported in Tables 3 and 4, the UHPLC-HRMS-based method allowed the identification and quantification of eighteen selected phenolic substances belonging to different phenolic classes: hydroxycinnamic, hydroxybenzoic, and methoxybenzoic acids, aldehydes, flavonoids and others.

By and large, the most abundant compound was 4-hydroxybenzoic acid in all ethanolic extracts except in $55-\mathrm{A}_{10} \mathrm{R}_{90}$, where the most abundant phenol was tyrosol $(1048.8 \mathrm{mg} / \mathrm{kg}$ in extract corresponding to $6.47 \mathrm{mg} / 100 \mathrm{~g}$ in dry SCG). Only S7-R extract presented comparable amounts of CQA and 4-hydroxybenzoic acid. High value of tyrosol was found also in S3-A extract $(1084.0 \mathrm{mg} / \mathrm{kg}$ in extract corresponding to $11.85 \mathrm{mg} / 100 \mathrm{~g}$ in dry SCG). Moreover, the latter extract presented the highest content of vanillic acid and vanillin. To the best of our 
Table 2

Ethanolic extraction yield and tocopherol contents in SCGs ethanolic extracts.

\begin{tabular}{|c|c|c|c|c|c|c|c|}
\hline & S1-A & $\mathrm{S} 2-\mathrm{A}$ & S3-A & $\mathrm{S} 4-\mathrm{A}_{60} \mathrm{R}_{40}$ & $\mathrm{~S} 5-\mathrm{A}_{10} \mathrm{R}_{90}$ & S6- $\mathrm{A}_{75} \mathrm{R}_{25}$ & S7-R \\
\hline $\begin{array}{l}\text { Ethanolic extraction yield } \\
\qquad(\mathrm{g} / 100 \mathrm{~g} \text { dry powder })\end{array}$ & $8.8 \pm 0.2^{\mathrm{c}}$ & $7.9 \pm 0.4^{c}$ & $11.2 \pm 0.4^{\mathrm{d}}$ & $7.9 \pm 0.3^{b}$ & $6.1 \pm 0.2^{\mathrm{a}}$ & $9.1 \pm 0.1^{\mathrm{c}}$ & $5.8 \pm 0.2^{\mathrm{a}}$ \\
\hline Total tocopherol content (mg/Kg ethanolic extract) & $1142 \pm 49^{\mathrm{e}}$ & $1508 \pm 14^{\mathrm{f}}$ & $1005 \pm 10^{\mathrm{d}}$ & $913 \pm 3^{c}$ & $822 \pm 17^{\mathrm{b}}$ & $905 \pm 36^{\mathrm{c}}$ & $299 \pm 1^{\mathrm{a}}$ \\
\hline$\alpha$-Tocopherol & $345 \pm 4^{\mathrm{b}}$ & $516 \pm 12^{\mathrm{d}}$ & $309 \pm 2^{b}$ & $344 \pm 5^{b}$ & $417 \pm 24^{c}$ & $414 \pm 22^{\mathrm{c}}$ & $165 \pm 1^{\mathrm{a}}$ \\
\hline$\beta$-Tocopherol & $796 \pm 45^{\mathrm{f}}$ & $991 \pm 14^{g}$ & $697 \pm 8^{\mathrm{e}}$ & $569 \pm 3^{\mathrm{d}}$ & $405 \pm 85^{b}$ & $492 \pm 31^{\mathrm{c}}$ & $134 \pm 1^{\mathrm{a}}$ \\
\hline$\alpha / \beta$ ratio & 0.4 & 0.5 & 0.4 & 0.6 & 1.0 & 0.8 & 1.2 \\
\hline
\end{tabular}

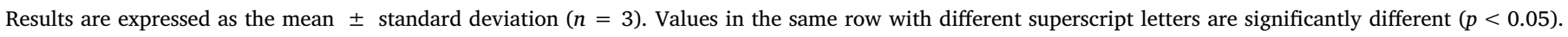

knowledge, this is the first study reporting the presence of tyrosol in coffee samples. The amount of tyrosol that has been found in S3-A, S4$A_{60} R_{40}$ and $S 5-A_{10} R_{90}$ ethanolic extracts is very high, even if compared to the levels usually encountered in matrices notoriously rich in tyrosol, such as olive oils for which European Food Safety Authority (EFSA) has approved an health claim on polyphenols, that may be used for olive oil containing at least $5 \mathrm{mg}$ of hydroxytyrosol and its derivatives (e.g. oleuropein complex and tyrosol) per $20 \mathrm{~g}$ of olive oil $(250 \mathrm{mg} / \mathrm{kg})$ (European Commission, 2012). In light of this, ethanolic extracts from espresso spent coffee may represent valuable alternative sources of tyrosol, as well as of other phenolic compounds, to be used in nutraceutical or dietary supplement formulations.

However, our results showed great variability of the phenolic profile among the SCG ethanolic extracts without any clear relation with the coffee variety (arabica or robusta) and with the mixture composition (arabica/robusta ratio). For instance, significantly higher $(p<0.05)$ value of monocaffeoylquinic acids (CQA, chlorogenic acids isomers) was found in S7-R and the significantly lower in $S 5-\mathrm{A}_{10} \mathrm{R}_{90}$. These extracts presented also a level of 4-hydroxybenzoic acid statistically different. Both SCGs samples derived from coffee mixture mainly formed by robusta variety. Anyway, the geographical origin of robusta variety was different: S7-R contained $100 \%$ robusta from Guatemala whereas $S 5-A_{10} R_{90}$ contained $90 \%$ of robusta from Vietnam and India.

Comparing our results with those reported in literature, it is noteworthy to underline that the investigated SCGs ethanolic extracts contained lower levels of CQA, than SCGs aqueous extracts investigated by others. In our case, CQA range from 80.8 to $1262.4 \mathrm{mg} / \mathrm{kg}$ of ethanolic extract in $\mathrm{S}_{5}-\mathrm{A}_{10} \mathrm{R}_{90}$ (10\% Arabica/90\% robusta) and S7-R (100\% robusta from Guatemala) samples, respectively. Referring the values to dry spent powder, the CQA levels range from 0.5 to $7.33 \mathrm{mg} / 100 \mathrm{~g}$ dry powder in $S 5-A_{10} R_{90}$ and S7-R, respectively. According to Monente et al. (2015b), arabica SCG water extract contained CQA at $82190 \mathrm{mg}$ / $\mathrm{kg}$ in lyophilized extract whereas robusta SCG water extract contained $63,280 \mathrm{mg} / \mathrm{Kg}$ in lyophilized extract. CQA and dicaffeoylquinic (diCQA) acids were also quantified in SCG obtained from different coffeemakers (filter, espresso, plunger, and mocha) by Bravo et al. (2012). Espresso SCG presented levels of total caffeoylquinic acids ranging from 7.49 to $11.05 \mathrm{mg} / \mathrm{g}$ of robusta (from Vietnam) and arabica

Table 3

Polyphenols content (mg/kg ethanolic extract) in SCGs samples.

\begin{tabular}{|c|c|c|c|c|c|c|c|}
\hline & \multicolumn{7}{|c|}{$\mathrm{mg} / \mathrm{kg}$ ethanolic extract } \\
\hline & S1-A & S2-A & S3-A & $\mathrm{S} 4-\mathrm{A}_{60} \mathrm{R}_{40}$ & $\mathrm{~S} 5-\mathrm{A}_{10} \mathrm{R}_{90}$ & $\mathrm{~S} 6-\mathrm{A}_{75} \mathrm{R}_{25}$ & S7-R \\
\hline \multicolumn{8}{|l|}{ Hydroxycinnamic acids } \\
\hline$p$-Coumaric acid & $16.5 \pm 0.0^{\mathrm{d}}$ & $10.5 \pm 0.1^{\mathrm{c}}$ & $36.7 \pm 0.1^{\mathrm{e}}$ & $19.1 \pm 0.0^{\mathrm{d}}$ & $30.0 \pm 0.3^{\mathrm{e}}$ & $1.2 \pm 0.0^{\mathrm{a}}$ & $5.8 \pm 0.1^{\mathrm{b}}$ \\
\hline Chlorogenic acids* & $281.8 \pm 7.6^{d}$ & $203.4 \pm 4.5^{\mathrm{b}, \mathrm{c}}$ & $118.7 \pm 1.0^{\mathrm{b}}$ & $99.8 \pm 0.6^{\mathrm{b}}$ & $80.8 \pm 0.3^{\mathrm{a}}$ & $143.0 \pm 4.3^{c}$ & $1262.4 \pm 15.7^{\mathrm{e}}$ \\
\hline Caffeic acid & $6.5 \pm 0.1^{\mathrm{a}}$ & $5.4 \pm 0.0^{\mathrm{a}}$ & $9.6 \pm 0.0^{\mathrm{b}}$ & $5.8 \pm 0.1^{\mathrm{a}}$ & $8.8 \pm 0.1^{b}$ & $4.9 \pm 0.0^{\mathrm{a}}$ & $11.2 \pm 0.0^{\mathrm{b}, \mathrm{c}}$ \\
\hline Ferulic acid & $356.4 \pm 3.2^{\mathrm{e}}$ & $207.6 \pm 1.6^{\mathrm{b}, \mathrm{c}}$ & $297.1 \pm 1.2^{\mathrm{d}}$ & $254.2 \pm 2.0^{c}$ & $221.2 \pm 0.3^{\mathrm{b}, \mathrm{c}}$ & $157.0 \pm 0.1^{\mathrm{b}}$ & $105.3 \pm 0.4^{\mathrm{a}}$ \\
\hline \multicolumn{8}{|l|}{ Hydroxybenzoic acids } \\
\hline 4-Hydroxybenzoic acid & $1812.7 \pm 8.5^{\mathrm{c}, \mathrm{d}}$ & $1386.5 \pm 46.9^{\mathrm{b}, \mathrm{c}}$ & $1789.1 \pm 14.2^{\mathrm{d}}$ & $1513.3 \pm 4.5^{\mathrm{b}, \mathrm{c}}$ & $884.7 \pm 2.2^{\mathrm{a}}$ & $1011.7 \pm 12.2^{\mathrm{b}}$ & $1522.0 \pm 14.2^{\mathrm{b}}$ \\
\hline Procatecuic acid & $9.7 \pm 0.1^{\mathrm{b}}$ & nd & $12.5 \pm 0.3^{\mathrm{c}}$ & $18.4 \pm 0.2^{\mathrm{d}}$ & $17.4 \pm 0.2^{\mathrm{d}}$ & $7.1 \pm 0.1^{\mathrm{b}}$ & $3.2 \pm 0.1^{\mathrm{a}}$ \\
\hline Vanillic acid & $330.4 \pm 3.2^{\mathrm{c}}$ & $121.7 \pm 1.2^{\mathrm{a}, \mathrm{b}}$ & $473.6 \pm 12.1^{\mathrm{e}}$ & $148.5 \pm 1.3^{\mathrm{b}}$ & $329.1 \pm 2.5^{c}$ & $132.6 \pm 0.2^{\mathrm{b}}$ & $98.9 \pm 1.3^{\mathrm{a}}$ \\
\hline Syringic acid & $129.8 \pm 0.4^{\mathrm{b}}$ & $58.9 \pm 0.4^{\mathrm{a}}$ & $219.5 \pm 4.5^{\mathrm{d}}$ & $135.7 \pm 0.6^{\mathrm{b}}$ & $148.9 \pm 0.4^{c}$ & $152.4 \pm 7.2^{\mathrm{c}}$ & $125.9 \pm 0.4^{\mathrm{b}}$ \\
\hline \multicolumn{8}{|l|}{ Methoxybenzoic acids } \\
\hline Veratric acid & $419.9 \pm 3.2^{\mathrm{e}}$ & $147.9 \pm 0.2^{\mathrm{b}}$ & $461.8 \pm 7.9^{e}$ & $410.7 \pm 2.2^{\mathrm{e}}$ & $346.3 \pm 3.0^{c}$ & $322.8 \pm 3.8^{\mathrm{d}}$ & $61.9 \pm 0.7^{\mathrm{a}}$ \\
\hline \multicolumn{8}{|l|}{ Aldehyde } \\
\hline Protocatechuic aldehyde & $48.3 \pm 3.2^{\mathrm{b}}$ & nd & $47.6 \pm 0.6^{c}$ & $40.3 \pm 0.2^{\mathrm{d}}$ & $23.4 \pm 0.1^{\mathrm{a}}$ & $26.8 \pm 0.3^{\mathrm{a}}$ & $40.8 \pm 1.4^{\mathrm{b}}$ \\
\hline Syringaldehyde & $85.4 \pm 1.6^{\mathrm{d}}$ & $34.3 \pm 0.2^{\mathrm{b}}$ & $94.5 \pm 1.3^{\mathrm{e}}$ & $83.0 \pm 0.5^{\mathrm{d}}$ & $73.2 \pm 4.4^{\mathrm{b}, \mathrm{c}}$ & $65.9 \pm 1.0^{\mathrm{c}, \mathrm{d}}$ & $18.7 \pm 0.1^{\mathrm{a}}$ \\
\hline Vanillin & $556.6 \pm 2.7^{\mathrm{d}}$ & $350.4 \pm 1.5^{\mathrm{a}, \mathrm{b}}$ & $1103.4 \pm 1.6^{\mathrm{e}}$ & $339.8 \pm 2.0^{\mathrm{a}, \mathrm{b}}$ & $728.9 \pm 4.7^{\mathrm{c}, \mathrm{d}}$ & $357.0 \pm 1.6^{\mathrm{b}, \mathrm{c}}$ & $341.9 \pm 2.0^{\mathrm{a}}$ \\
\hline $\begin{array}{l}\text { Flavonoids } \\
(+) \text {-Catechin }\end{array}$ & & $1.4 \pm 0.0^{\mathrm{a}}$ \\
\hline Epicatechin & $2.9 \pm 0.0^{\mathrm{b}}$ & $1.1 \pm 0.1^{\mathrm{a}}$ & $2.7 \pm 0.0^{\mathrm{b}}$ & $2.4 \pm 0.0^{\mathrm{b}}$ & $5.2 \pm 0.0^{c}$ & $1.3 \pm 0.1^{\mathrm{a}}$ & $5.3 \pm 0.3^{\mathrm{c}}$ \\
\hline \multicolumn{8}{|l|}{ Other } \\
\hline Ethylgallate & $3.0 \pm 0.0^{\mathrm{b}}$ & $2.3 \pm 0.0^{\mathrm{a}}$ & $3.0 \pm 0.0^{\mathrm{b}}$ & $3.0 \pm 0.2^{\mathrm{b}}$ & $4.9 \pm 0.2^{c}$ & $3.5 \pm 0.1^{\mathrm{b}}$ & $3.6 \pm 0.1^{\mathrm{b}}$ \\
\hline Tyrosol & $192.3 \pm 0.5^{\mathrm{c}}$ & $121.1 \pm 0.7^{\mathrm{b}}$ & $1084.0 \pm 8.7^{\mathrm{e}}$ & $408.2 \pm 4.3^{\mathrm{d}}$ & $1048.8 \pm 3.0^{\mathrm{f}}$ & $212.6 \pm 0.6^{c}$ & $143.4 \pm 0.8^{\mathrm{a}}$ \\
\hline D-(-)-Quinic acid & $61.8 \pm 0.1^{\mathrm{c}}$ & $39.0 \pm 0.4^{\mathrm{b}}$ & $43.8 \pm 0.6^{\mathrm{b}}$ & $20.6 \pm 0.5^{\mathrm{a}}$ & $41.6 \pm 0.3^{\mathrm{b}}$ & $22.3 \pm 0.2^{\mathrm{a}}$ & nd \\
\hline Homovanillic acid & $119.4 \pm 0.8^{\mathrm{c}}$ & $48.7 \pm 0.3^{\mathrm{b}}$ & $133.2 \pm 1.9^{\mathrm{d}}$ & $114.2 \pm 2.3^{\mathrm{c}}$ & $102.4 \pm 2.7^{\mathrm{b}}$ & $97.1 \pm 5.0^{\mathrm{c}}$ & $27.7 \pm 0.1^{\mathrm{a}}$ \\
\hline
\end{tabular}

Values in each row having different lowercase letters are significantly different at $\mathrm{p}<0.05$.

* Chlorogenic acids = sum of monocaffeoylquinic acids isomers (3-CQA + 4-CQA + 5-CQA, molecular weight = 354); n.d.: not detectable (< LOD); Limit of

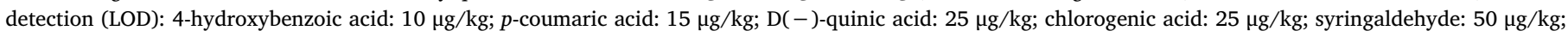

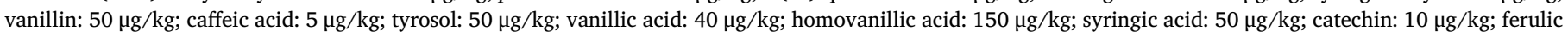
acid: $50 \mu \mathrm{g} / \mathrm{kg}$; veratric acid: $70 \mu \mathrm{g} / \mathrm{kg}$; protocatechuic aldehyde: $5 \mu \mathrm{g} / \mathrm{kg}$; epicatechin: $10 \mu \mathrm{g} / \mathrm{kg}$; ethyl gallate: $30 \mu \mathrm{g} / \mathrm{kg}$; protocatechuic acid: $10 \mu \mathrm{g} / \mathrm{kg}$. 
Table 4

Polyphenols content (mg/100 g dry powder) in SCGs samples.

\begin{tabular}{|c|c|c|c|c|c|c|c|}
\hline & \multicolumn{7}{|c|}{$\mathrm{mg} / 100 \mathrm{~g}$ dry powder } \\
\hline & S1-A & S2-A & S3-A & $\mathrm{S} 4-\mathrm{A}_{60} \mathrm{R}_{40}$ & S5- $A_{10} R_{90}$ & S6- $\mathrm{A}_{75} \mathrm{R}_{25}$ & S7-R \\
\hline \multicolumn{8}{|l|}{ Hydroxycinnamic acids } \\
\hline$p$-Coumaric acid & $0.14 \pm 0.03^{b, c}$ & $0.09 \pm 0.02^{\mathrm{b}}$ & $0.40 \pm 0.02^{\mathrm{d}}$ & $0.15 \pm 0.01^{\mathrm{c}}$ & $0.19 \pm 0.0^{\mathrm{c}}$ & $0.01 \pm 0.01^{\mathrm{a}}$ & $0.03 \pm 0.01^{\mathrm{a}}$ \\
\hline Chlorogenic acids & $2.40 \pm 0.12^{\mathrm{e}}$ & $1.72 \pm 0.36^{\mathrm{d}}$ & $1.30 \pm 0.05^{\mathrm{c}}$ & $0.79 \pm 0.03^{b}$ & $0.50 \pm 0.0^{\mathrm{a}}$ & $1.32 \pm 0.21^{\mathrm{c}}$ & $7.33 \pm 0.61^{\mathrm{f}}$ \\
\hline Caffeic acid & $0.06 \pm 0.0^{\mathrm{a}, \mathrm{b}}$ & $0.05 \pm 0.01^{\mathrm{a}}$ & $0.10 \pm 0.0^{c}$ & $0.05 \pm 0.01^{\mathrm{a}}$ & $0.05 \pm 0.0^{\mathrm{a}}$ & $0.05 \pm 0.01^{\mathrm{a}}$ & $0.06 \pm 0.01^{\mathrm{a}, \mathrm{b}}$ \\
\hline Ferulic acid & $3.04 \pm 0.15^{\mathrm{d}}$ & $1.76 \pm 0.36^{\mathrm{b}, \mathrm{c}}$ & $3.26 \pm 0.13^{\mathrm{d}}$ & $2.01 \pm 0.08^{\mathrm{c}}$ & $1.36 \pm 0.01^{\mathrm{b}}$ & $1.45 \pm 0.28^{\mathrm{b}, \mathrm{c}}$ & $0.61 \pm 0.05^{\mathrm{a}}$ \\
\hline \multicolumn{8}{|l|}{ Hydroxybenzoic acids } \\
\hline 4-Hydroxybenzoic acid & $15.24 \pm 3.30^{\mathrm{c}, \mathrm{d}}$ & $11.74 \pm 2.43^{\mathrm{b}, \mathrm{c}}$ & $19.56 \pm 0.80^{\mathrm{d}}$ & $11.95 \pm 0.49^{\mathrm{b}, \mathrm{c}}$ & $5.46 \pm 0.04^{\mathrm{a}}$ & $9.36 \pm 1.52^{\mathrm{b}}$ & $8.83 \pm 0.84^{\mathrm{b}}$ \\
\hline Procatecuic acid & $0.08 \pm 0.0^{\mathrm{a}}$ & nd & $0.14 \pm 0.01^{\mathrm{d}}$ & $0.15 \pm 0.01^{\mathrm{d}}$ & $0.11 \pm 0.0^{\mathrm{c}}$ & $0.07 \pm 0.01^{\mathrm{b}}$ & $0.02 \pm 0.0^{\mathrm{a}}$ \\
\hline Vanillic acid & $2.82 \pm 0.14^{\mathrm{d}}$ & $1.03 \pm 0.21^{\mathrm{a}, \mathrm{b}}$ & $5.18 \pm 0.21^{\mathrm{e}}$ & $1.17 \pm 0.05^{\mathrm{b}}$ & $2.03 \pm 0.02^{c}$ & $1.23 \pm 0.02^{\mathrm{b}}$ & $0.57 \pm 0.05^{\mathrm{a}}$ \\
\hline Syringic acid & $1.11 \pm 0.05^{\mathrm{c}, \mathrm{d}}$ & $0.50 \pm 0.1^{\mathrm{a}}$ & $2.40 \pm 0.1^{\mathrm{e}}$ & $1.07 \pm 0.04^{\mathrm{b}, \mathrm{d}}$ & $0.92 \pm 0.01^{\mathrm{b}, \mathrm{c}}$ & $1.41 \pm 0.23^{\mathrm{d}}$ & $0.73 \pm 0.06^{\mathrm{a}, \mathrm{b}}$ \\
\hline \multicolumn{6}{|l|}{ Methoxybenzoic acids } & $2.99 \pm 0.48^{\mathrm{d}}$ & $0.36 \pm 0.03^{a}$ \\
\hline \multicolumn{8}{|l|}{ Aldehyde } \\
\hline Protocatechuic aldehyde & $0.41 \pm 0.02^{\mathrm{c}}$ & nd & $0.52 \pm 0.02^{\mathrm{e}}$ & $0.32 \pm 0.01^{\mathrm{d}}$ & $0.14 \pm 0.0^{\mathrm{a}}$ & $0.25 \pm 0.04^{\mathrm{b}}$ & $0.24 \pm 0.02^{\mathrm{b}}$ \\
\hline Syringaldehyde & $0.73 \pm 0.04^{\mathrm{d}}$ & $0.29 \pm 0.06^{\mathrm{b}}$ & $1.03 \pm 0.04^{\mathrm{e}}$ & $0.66 \pm 0.03^{d}$ & $0.45 \pm 0.0^{\mathrm{b}, \mathrm{c}}$ & $0.61 \pm 0.1^{c, d}$ & $0.11 \pm 0.01^{\mathrm{a}}$ \\
\hline Vanillin & $4.74 \pm 0.23^{\mathrm{d}}$ & $2.97 \pm 0.61^{\mathrm{a}, \mathrm{b}}$ & $12.06 \pm 0.49^{\mathrm{e}}$ & $2.68 \pm 0.11^{\mathrm{a}, \mathrm{b}}$ & $4.50 \pm 0.03^{\mathrm{c}, \mathrm{d}}$ & $3.30 \pm 0.53^{\mathrm{b}, \mathrm{c}}$ & $1.98 \pm 0.17^{\mathrm{a}}$ \\
\hline \multicolumn{8}{|l|}{ Flavonoids } \\
\hline$(+)$-Catechin & $0.02 \pm 0.0$ & $0.01 \pm 0.0$ & $0.03 \pm 0.0$ & $0.02 \pm 0.0$ & $0.01 \pm 0.0$ & $0.01 \pm 0.0$ & $0.01 \pm 0.0$ \\
\hline Epicatechin & $0.02 \pm 0.0$ & $0.01 \pm 0.0$ & $0.03 \pm 0.0$ & $0.02 \pm 0.0$ & $0.03 \pm 0.0$ & $0.01 \pm 0.0$ & $0.03 \pm 0.0$ \\
\hline \multicolumn{8}{|l|}{ Other } \\
\hline Ethylgallate & $0.03 \pm 0.0$ & $0.01 \pm 0.0$ & $0.03 \pm 0.0$ & $0.02 \pm 0.0$ & $0.01 \pm 0.0$ & $0.01 \pm 0.0$ & $0.01 \pm 0.0$ \\
\hline Tyrosol & $1.64 \pm 0.08^{\mathrm{a}, \mathrm{b}}$ & $1.03 \pm 0.21^{\mathrm{a}}$ & $11.85 \pm 0.48^{\mathrm{e}}$ & $3.22 \pm 0.13^{c}$ & $6.47 \pm 0.05^{\mathrm{d}}$ & $1.97 \pm 0.32^{\mathrm{b}}$ & $0.83 \pm 0.07^{\mathrm{a}}$ \\
\hline D-(-)-Quinic acid & $0.52 \pm 0.11^{\mathrm{c}}$ & $0.33 \pm 0.07^{\mathrm{a}, \mathrm{b}}$ & $0.48 \pm 0.02^{\mathrm{b}, \mathrm{c}}$ & $0.16 \pm 0.01^{\mathrm{a}}$ & $0.26 \pm 0.0^{\mathrm{a}}$ & $0.21 \pm 0.03^{\mathrm{a}}$ & nd \\
\hline Homovanillic acid & $1.02 \pm 0.05^{\mathrm{c}}$ & $0.41 \pm 0.09^{\mathrm{b}}$ & $1.46 \pm 0.06^{\mathrm{d}}$ & $0.90 \pm 0.04^{c}$ & $0.63 \pm 0.0^{\mathrm{b}}$ & $0.90 \pm 0.14^{\mathrm{c}}$ & $0.16 \pm 0.01^{\mathrm{a}}$ \\
\hline
\end{tabular}

Values are the mean \pm standard deviation of three replicates. Values in each row having different lowercase letters are significantly different at $p<0.05$.

* Chlorogenic acids = sum of monocaffeoylquinic acids isomers (3-CQA + 4-CQA + 5-CQA, molecular weight = 354); n.d.: not detectable (< LOD).

(from Guatemala), respectively. Cruz et al. (2012) found that the total content of chlorogenic acids varying from 2.12 to $7.66 \mathrm{mg} / \mathrm{g}$ of espresso SGC, and Panusa, Zuorro, Lavecchia, Marrosu, and Petrucci (2013) found a total chlorogenic content ranging from 1.81 to $6.09 \mathrm{mg} / \mathrm{g}$ in dry espresso SCG.

Similarly, Lopez-Barrera, Vazquez-Sanchez, Loarca-Pina, and Campos-Vega (2016) also reported higher levels of chlorogenic acid (from 1.8 to $5.6 \mathrm{mg} / \mathrm{g} \mathrm{SGC}$ ) compared with our study. The observed differences might be related to the natural matrix variability and, also to the different solvent and analytical procedure used for the spent coffee extraction. While in the present study a cold ethanol extraction $\left(25^{\circ} \mathrm{C}\right.$ for $12 \mathrm{~h}$ ) was performed, López-Barrera et al. (2016) conducted a microwave extraction using $20 \%$ ethanol solution (1:9 solid/liquid ratio) whereas Bravo, Monente, Juániz, Paz De Peña, and Cid (2013) extracted spent coffee samples with water at $90{ }^{\circ} \mathrm{C}$. Such differences may affect the quali-quantitative profile of phenolic fraction and explain such dissimilarities (Pettinato, Casazza, \& Perego, 2019).

\subsection{Antioxidant activity}

To counteract oxidative stress, the consumption of dietary antioxidants is important in order to prevent the development of several diseases. Different in vitro assays were used to investigate the antiradical and/or antioxidant effects of SCG extracts. A multiple approach to test the antioxidant potential of sample is strongly recommended. The radical scavenging activity evidences the ability of sample to react with free radicals, while with antioxidant activity researchers refer to all the other mechanisms involved in the process (Tirzitis \& Bartosz, 2010).

Generally, a concentration-effect relationship was found in all the tests, except in FRAP assay (Table 5). S7-R (100\% robusta from Guatemala) sample showed the highest DPPH radical scavenging potential with IC $_{50}$ value of $1.5 \mu \mathrm{g} / \mathrm{mL}$. In ABTS test promising results were obtained by S7-R, S6- $\mathrm{A}_{75} \mathrm{R}_{25}$ alues of $1.5,4.5$ and $5.9 \mu \mathrm{g} / \mathrm{mL}$, respectively. This finding could be related to the relevant amount of CQA and it reinforces the results found by $\mathrm{Xu}, \mathrm{Hu}$, and Liu (2012) whose demonstrated that both CQA and di-CQA are able to scavenge DPPH - and ABTS ${ }^{+}$radicals. The highest reductant potential in FRAP assay was obtained with $\mathrm{S} 5-\mathrm{A}_{10} \mathrm{R}_{90}$ extract (FRAP value of $100.5 \mu \mathrm{M}$ Fe (II)/g). This value was quite higher than that reported for the positive control BHT $(63.2 \mu \mathrm{M} \mathrm{Fe}(\mathrm{II}) / \mathrm{g})$. It is interesting to note that this sample showed a high amount of tyrosol. Pearson's correlation coefficient $(r)$ evidenced a positive correlation between this compound and FRAP assay ( $r=0.59$ ). The antioxidant potential of SCG extracts was evaluated also using the $\beta$-carotene bleaching test, which consists in the evaluation of the ability of the extract to inhibit the lipid peroxidation. Since no high temperatures are required, the antioxidant activity of thermo-sensitive compounds may be determined and quantitatively evaluated. Except for decaffeinated sample $\left(S 6-A_{75} R_{25}\right)$, SCG extracts showed a promising protection of lipid peroxidation. The following samples exhibited the most promising protection of lipid peroxidation with $\mathrm{IC}_{50}$ values of $10.7,12.5,13$, and $13.4 \mu \mathrm{g} / \mathrm{mL}$ for S1-A, S2-A, S7-R, and S3-A, respectively.

Two indices, namely Relative Antioxidant Capacity Index (RACI) and Global Antioxidant Score (GAS), were calculated in an integrated approach to evaluate and create a ranking clustering of the antioxidant capacity of different samples. Based on both RACI and GAS values, S7-R extract (100\% robusta from Guatemala) showed the highest antioxidant potential. Differently from all the other extracts, phenolic profile of S7$\mathrm{R}$ sample was characterized by the highest CQA content and by comparable amounts of CQA and 4-hydroxybenzoic acid. However, Pearson's correlation coefficient calculation demonstrated that chlorogenic acid and hydroxybenzoic acid alone do not account for the antioxidant activity. A possible synergism of action between SCGs components should be hypothesized. Differently, ferulic and veratric acids positively correlated with ABTS test $(r=0.69)$.

A significant correlation was found also for tyrosol and ABTS with $r$ value of 0.87 . Ethyl gallate positively correlate with FRAP assay $(r=0.89)$. No correlations were evidenced between tocopherols content and antioxidant activities. 
Table 5

Antioxidant activity of SCGs ethanolic extracts.

\begin{tabular}{|c|c|c|c|c|c|c|}
\hline Extracts & $\begin{array}{l}\text { DPPH } \\
\mathrm{IC}_{50}(\mu \mathrm{g} / \mathrm{mL})\end{array}$ & $\begin{array}{l}\text { ABTS } \\
\mathrm{IC}_{50}(\mu \mathrm{g} / \mathrm{mL})\end{array}$ & $\begin{array}{l}\text { FRAP } \\
\text { IC }_{50}(\mu \mathrm{M} \mathrm{Fe}(\mathrm{II}) / \mathrm{g}) \\
\text { at } 2.5 \mathrm{mg} / \mathrm{mL}\end{array}$ & $\beta$-Carotene bleaching test $\mathrm{IC}_{50}(\mu \mathrm{g} / \mathrm{mL})$ & RACI & GAS \\
\hline S1-A & $49.7 \pm 2.9^{* * * *}$ & $5.9 \pm 0.4$ & $18.3 \pm 2.5^{* * * *}$ & $10.7 \pm 1.4^{* *}$ & -0.34 & 0.33 \\
\hline S2_A & $83.9 \pm 4.7^{\text {*:**:* }}$ & $17.9 \pm 1.1^{* * * * *}$ & $13.6 \pm 2.1^{* * * * *}$ & $12.5 \pm 1.9^{* * *}$ & 0.38 & 1.44 \\
\hline S3-A & $301.8 \pm 5.2^{* * * * *}$ & $164.8 \pm 3.7^{* * * * *}$ & $17.3 \pm 1.1^{* * * * *}$ & $13.4 \pm 1.7^{* * * * *}$ & 0.43 & 2.79 \\
\hline $\mathrm{S} 4-\mathrm{A}_{60} \mathrm{R}_{40}$ & $272.9 \pm 6.3^{* * * * *}$ & $162.8 \pm 2.9^{* * * * *}$ & $6.4 \pm 0.3^{* * * * *}$ & $34.9 \pm 2.5^{\text {:*****}}$ & 0.21 & 2.51 \\
\hline S5- $A_{10} R_{90}$ & $48.9 \pm 2.0^{\text {***** }}$ & $185.7 \pm 3.3^{* * * *}$ & $100.5 \pm 3.6^{* * * *}$ & $36.8 \pm 3.9^{* * * * *}$ & -0.32 & 2.58 \\
\hline $\mathrm{S} 6-\mathrm{A}_{75} \mathrm{R}_{25}$ & $182.9 \pm 4.8^{* * * * *}$ & $4.5 \pm 0.5$ & $20.6 \pm 2.0^{* * * * *}$ & $86.6 \pm 4.0^{* * * * *}$ & 0.29 & 2.66 \\
\hline S7-R & $10.1 \pm 2.1$ & $1.5 \pm 0.9$ & $22.8 \pm 2.4^{* * * * *}$ & $13.0 \pm 1.5^{* * * *}$ & -0.43 & 0.20 \\
\hline
\end{tabular}

Positive controls

Ascorbic acid

$5.0 \pm 0.8$

$1.7 \pm 0.06$

BHT

Propyl gallate

$63.2 \pm 4.3$

$1.0 \pm 0.04$

Data are given as media \pm S.D. $(n=3)$; DPPH Radical Scavenging Activity Assay; Antioxidant Capacity Determined by Radical Cation $\left(\mathrm{ABTS}^{+}\right)$, $\beta$-Carotene bleaching test, Ferric ion reducing antioxidant power (FRAP); Relative antioxidant capacity index (RACI); Global antioxidant score (GAS). Ascorbic acid, BHT and Propyl gallate were used as positive control in antioxidant tests. Differences within and between groups were evaluated by One-way ANOVA followed by a multicomparison Dunnett's test $(\alpha=0.01)$.

$* * * * \quad p<0.0001$.

*** $p<0.001$.

** $p<0.01$ compared to the positive controls.

\subsection{Anti-proliferative activity}

In cancer, altered cellular pathways determine an abnormal tendency for uncontrolled growth. Several phytochemicals able to targeting diverse oncogenic pathways can be used as chemopreventive agent or in the treatment of this complex disease. In the present study, SCGs extracts were screened against seven cancer cell lines. All investigated samples except S3-A showed a concentration-dependent activity. Promising $I_{50}$ values were found with S7-R and S6- $A_{75} R_{25}$ extracts against human lung carcinoma cells (A549) with values of 61.2 and $61.3 \mu \mathrm{g} / \mathrm{mL}$, respectively. Both values are in the same order of potency of the positive control vinblastine $\left(\mathrm{IC}_{50}\right.$ value of $67.3 \mu \mathrm{g} / \mathrm{mL}$ ) (Table 6). The same samples evidenced a similar anti-proliferative activity against human amelanotic melanoma cells with $\mathrm{IC}_{50}$ values 1.6-

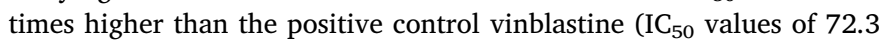
and $74.7 \mu \mathrm{g} / \mathrm{mL}$, respectively). S1-A showed the highest anti-proliferative activity against human uterine cervix adenocarcinoma (HeLa) and human prostate cancer (PC3) cells with IC $_{50}$ value of 39.7 , and $40.0 \mu \mathrm{g} / \mathrm{mL}$, respectively. Previously, Ramalakshmi et al. (2009) evidenced that SCGs extracts obtained by arabica and robusta varieties were able to inhibit P388 cell used as model of leukaemia. These extracts showed higher potency in cell viability inhibition in comparison to the extracts obtained by green coffees. Chemically spent coffee extracts are characterized by a lower content of polyphenols but are richest in melanoidins and phenolic polymers, which are found able to protect cells from oxidative damage (Wen, Takenaka, Murata, \& Homma, 2004).

Except for ethyl gallate that correlated with HeLa cells $(r=0.59)$, no significant positive correlations between the identified compounds and anti-proliferative activity were found. According literature data, ethyl gallate exhibited a promising activity against several cancer cell lines including IHH, PC3, Hep3B, HepG2, HeLa and CaSKi cells with $\mathrm{IC}_{50}$ values ranging from 38 to $211 \mu \mathrm{M}$ for Hep3B and $\mathrm{IHH}$, respectively. This compound could induce G2/M phase cell cycle arrest and display interesting effect on microtubule stabilization in Hep3B cells. The activation of caspase $3 / 7$ and increase in the ratio of $\mathrm{Bax} / \mathrm{Bcl}-2$ expression was also observed (Sánchez-Carranza et al., 2017). The antiproliferative activity of ethyl gallate by apoptotic pathway was proved also against human oral squamous carcinoma cell line KB (Mohan, Thiagarajan, \& Chandrasekaran, 2015). Other identified phytochemicals in SCGs samples are previously investigated as antitumor agents. Quiles, Farquharson, Simpson, Grant, and Wahle (2002) evidenced the ability of tyrosol to reduce DNA oxidation and to increase the levels of glutathione peroxidase and hydroperoxides in PC3 cell line.

Table 6

Anti-proliferative activity of SCGs ethanolic extract ( $\mathrm{IC}_{50}$ in $\mu \mathrm{g} / \mathrm{mL}$ ).

\begin{tabular}{|c|c|c|c|c|c|c|c|}
\hline Extracts & MCF-7 & HeLa & MDA-MB-231 & C32 & A549 & LNCaP & PC3 \\
\hline S1-A & $52.4 \pm 4.0^{* * * * *}$ & $39.7 \pm 2.8^{\text {*:**** }}$ & $124.7 \pm 3.3^{* * * * * *}$ & $105.7 \pm 3.1^{* * * * *}$ & $121.4 \pm 3.8^{* * * * *}$ & $46.8 \pm 4.2^{* * * * *}$ & $40.0 \pm 2.9^{* * * * *}$ \\
\hline S2-A & $82.4 \pm 3.2^{* * * * *}$ & $43.2 \pm 3.1^{* * * * *}$ & $143.2 \pm 3.6^{* * * * *}$ & $85.8 \pm 3.8^{* *}$ & $78.8 \pm 3.4 * *$ & $81.1 \pm 3.4^{* * * * *}$ & $75.3 \pm 3.8^{* * * *}$ \\
\hline S3-A & $>200$ & $>200$ & $>200$ & $>200$ & $>200$ & $>200$ & $>200$ \\
\hline $\mathrm{S} 4-\mathrm{A}_{60} \mathrm{R}_{40}$ & $>200$ & $>200$ & $>200$ & $>200$ & $145.2 \pm 3.9^{* * * * *}$ & $>200$ & $>200$ \\
\hline $\mathrm{S} 5-\mathrm{A}_{10} \mathrm{R}_{90}$ & $105.4 \pm 3.8^{* * * * *}$ & $78.5 \pm 3.4^{* * * * *}$ & $>200$ & $>200$ & $>200$ & $127.6 \pm 3.9^{* * * * *}$ & $101.3 \pm 3.6^{* * * * * *}$ \\
\hline S6- $A_{75} R_{25}$ & $184.7 \pm 3.3^{* * * * *}$ & $79.9 \pm 3.7^{\text {**:*** }}$ & $191.5 \pm 3.2^{* * * * *}$ & $74.7 \pm 3.3^{* * * * *}$ & $61.3 \pm 3.7$ & $195.1 \pm 3.7^{* * * * *}$ & $167.2 \pm 2.7^{\text {******}}$ \\
\hline S7-R & $75.5 \pm 4.3^{* * * * * *}$ & $71.9 \pm 3.8^{* * * * *}$ & $100.2 \pm 3.3^{* * * * * *}$ & $72.3 \pm 4.7^{* * * * *}$ & $61.2 \pm 3.5$ & $80.2 \pm 3.6^{* * * *}$ & $68.1 \pm 3.1^{* * * * *}$ \\
\hline \multicolumn{8}{|l|}{ Positive control } \\
\hline Vinblastine & & & & $45.5 \pm 1.9$ & $67.3 \pm 2.0$ & $29.3 \pm 0.9$ & \\
\hline Doxorubicin & $4.04 \pm 0.4$ & $3.6 \pm 0.3$ & $14.9 \pm 1.4$ & & & & $1.5 \pm 0.1$ \\
\hline
\end{tabular}

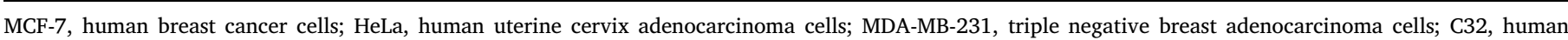

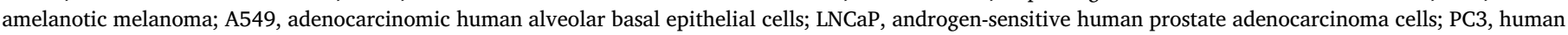

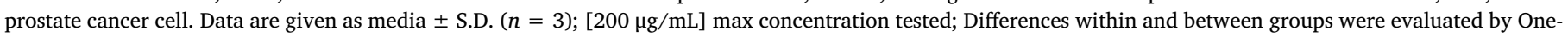
way ANOVA followed by a multicomparison Dunnett's test $(\alpha=0.01)$.

***** $p<0.0001$ compared to the positive controls (Vinblastine and Doxorubicin).

** $p<0.01$ compared to the positive controls (Vinblastine and Doxorubicin). 
Chlorogenic acids are known for their antioxidant and antitumor potential. Recently, Yamagata, Izawa, Onodera, and Tagami (2018) demonstrated that chlorogenic acids are able to decrease proliferation of A549 human lung cancer cells by regulation of apoptosis. In particular, among the most abundant identified phenols, the 4-hydroxybenzoic acid showed anti-proliferative and pro-apoptotic activities by inhibition of histone deacetylases (HDAC) whose pathological alteration determines the tumour progression (Seidel, Schnekenburger, Dicato, \& Diederich, 2014). In fact, although the link between hyperacetylation and apoptosis is not completely clarified, treatments with HDAC inhibitors usually lead to apoptosis induction (Marks \& Xu, 2009). With the same mechanism $p$-coumaric and ferulic acids act against cervical cancer cells (HeLa) (Waldecker, Kautenburger, Daumann, Busch, \& Schrenk, 2008).

\section{Conclusions}

The present work investigated the composition and bioactivity of ethanolic extracts from spent espresso coffee grounds obtained by using different arabica and robusta coffee mixtures and the same coffee brewing process parameters. The findings indicated that ethanolic extracts from espresso SCGs contain valuable antioxidant compounds, especially of $\alpha$ - and $\beta$-tocopherols, CQA, 4-hydroxybenzoic acid, vanillin and tyrosol, the last one to our knowledge identified for the first time in this matrix. Among investigated samples, the extract from $100 \%$ robusta Guatemala coffee (S7-R), showed promising anti-proliferative activity against A549 cell line with $\mathrm{IC}_{50}$ value $(61.2 \pm 3.5 \mu \mathrm{g} / \mathrm{mL})$ comparable to that given by vinblastine $(67.3 \pm 2.0 \mu \mathrm{g} / \mathrm{mL})$. Moreover, S7-R was characterized by a high phenolic content, particularly CQA and antioxidant potential. However, the high variability in terms of chemical composition and bioactivities found in the different samples investigated is to be considered if exploiting SCG as source of bioactive compounds. SCG is a complex matrix containing phytochemicals differing for molecular size, polarity, and solubility, parameters that may affect their bioavailability and distribution in different cells. Even if some specific correlations between chemical composition and bioactivity have been highlighted, further studies could better clarify these relationships and possible synergistic effects between the different components.

\section{Acknowledgements}

We thank the roasting company "Caffè del Faro", Montegranaro, Italy for providing the coffee samples.

\section{Funding}

This work was supported by Università Politecnica delle Marche (Ricerca di Ateneo 2017), University of Calabria (Ricerca di Ateneo 2017), Spanish Ministry of Economy and Competitiveness under the project CTQ2015-63968-C2-1-P and from the Agency for Administration of University and Research Grants (Generalitat de Catalunya, Spain) under the project 2017SGR-310.

\section{References}

Al-Hamamre, Z., Foerster, S., Hartmann, F., Kröger, M., \& Kaltschmitt, M. (2012). Oil extracted from spent coffee grounds as a renewable source for fatty acid methyl ester manufacturing. Fuel, 96, 70-76.

Alongi, M., \& Anese, M. (2018). Effect of coffee roasting on in vitroa-glucosidase activity: Inhibition andmechanism of action. Food Research International, 11, 480-487.

Alves, R. C., Casal, S., Alves, M. R., \& Oliveira, M. B. (2009). Discrimination between arabica and robusta coffe species con the basis of their tocopherol profiles. Food Chemistry, 114, 295-299.

Bravo, J., Monente, C., Juániz, I., Paz De Peña, M., \& Cid, C. (2013). Influence of extraction process on antioxidant capacity of spent coffee. Food Research International, 50, 610-616.

Brazilian Association of Coffee Industry - Associação Brasileira da Indústria de Café
(ABIC). http://abic.com.br/brasil-maior-produtor-mundial-de-cafe-exporta-3515milhoes-de-sacas-com-media-mensal-de-292-milhoes-de-sacas-em-2018/; accessed 5 September 2019.

Campos-Vega, R., Loarca-Pina, G., Vergara, H., \& Oomah, B. D. (2015). Spent coffee grounds: A review on current research and future prospects. Trends in Food Science \& Technology, 45, 24-36.

Cruz, R., Cardoso, M. M., Fernandes, L., Oliveira, M., Mendes, E., Baptista, P., ... Casal, S. (2012). Espresso coffee residues: A valuable source of unextracted compounds. Journal Agriculture Food Chemistry, 60, 7777-7784.

Directive 2008/98/EC (2008). Directive 2008/98/EC on waste (waste framework directive) environment. European Commission.

EU Publication (2012). Innovating for sustainable growth: A bioeconomy for Europe. ISBN 978-92-79-25376-8.

European Commission (2012). Commission Regulation (EU) no 432/2012 of 16 May 2012 establishing a list of permitted health claims made on foods, other than those referring to the reduction of disease risk and to children's development and health. Official Journal of the European Union, 136, 1-40.

Getachew, A. T., \& Chun, B. S. (2017). Influence of pretreatment and modifiers on subcritical water liquefaction of spent coffee grounds: A green waste valorization approach. Journal of Cleaner Production, 142, 3719-3727.

Giardinieri, A., Schicchi, R., Geraci, A., Rosselli, S., Maggi, F., Fiorini, D., ... Pacetti, D. (2019). Fixed oil from seeds of narrow-leaved ash (F. angustifolia subsp.angustifolia): Chemical profile, antioxidant and antiproliferative activities. Food Research International, 119, 369-377.

Górnaś, P., Siger, A., Pugajeva, I., Czubinski, J., Waskiewicz, A., \& Polewski, K. (2014). New insights regarding tocopherols in Arabica and Robusta species coffee beans: RPUPLC-ESI/MS ${ }^{\mathrm{n}}$ and NP-HPLC/FLD study. Journal of Food Composition and Analysis, 36, $117-123$.

International Coffee Organization (November 2018). Coffee market report.

Iriondo-DeHond, A., Aparicio García, N., Fernandez-Gomez, B., Guisantes-Batan, E., Velázquez Escobar, F., Blanch, G. P., ... del Castillo, M. D. (2019). Validation of coffee by-products as novel food ingredients. Innovative Food Science \& Emerging Technologies, 51, 194-204.

Janissen, B., \& Huynh, T. (2018). Chemical composition and value-adding applications of coffee industry by-products: A review. Resource Conservation and recycling, 128, $110-117$.

Jiménez-Zamora, A., Pastoriza, S., \& Rufián-Henares, J. A. (2015). Revalorization of coffee by-products. Prebiotic, antimicrobial and antioxidant properties. LWT - Food Science and Technology, 61, 12-18.

Kim, J. H., Ahn, D. U., Eun, J. B., \& Moon, S. H. (2016). Antioxidant effect of extracts from the coffee residue in raw and cooked meat. Antioxidants (Basel), 5(3), E21. https:// doi.org/10.3390/antiox5030021.

Loizzo, M. R., Lucci, P., Núñez, O., Tundis, R., Balzano, M., Frega, N. G., ... Pacetti, D. (2019). Native Colombian fruits and their by-products: Phenolic profile, antioxidant activity and hypoglycaemic potential. Foods, 8(3), 89.

Loizzo, M. R., Tundis, R., Bonesi, M., Menichini, F., De Luca, D., Colica, C., \& Menichini, F. (2012). Evaluation of Citrus aurantifolia peel and leaves extracts for their chemical composition, antioxidant and anti-cholinesterase activities. Journal Science Food Agriculture, 92, 2960-2967.

Lopez-Barrera, D. M., Vazquez-Sanchez, K., Loarca-Pina, M. G. F., \& Campos-Vega, R. (2016). Spent coffee grounds, an innovative source of colonic fermentable compounds, inhibit inflammatory mediators in vitro. Food Chemistry, 212, 282-290.

Lucci, P., Pacetti, D., Loizzo, M. R., \& Frega, N. G. (2015). Punica granatum cv. Dente di Cavallo seed ethanol extract: Antioxidant and antiproliferative activities. Food Chemistry, 167, 475-483.

Marks, P. A., \& Xu, W. S. (2009). Histone deacetylase inhibitors: Potential in cancer therapy. Journal of Cellular Biochemistry, 107, 600-608.

Mohan, S., Thiagarajan, K., \& Chandrasekaran, R. (2015). In vitro evaluation of antiproliferative effect of ethyl gallate against human oral squamous carcinoma cell line KB. Natural Product Research, 29(4), 366-369.

Monente, C., Bravo, J., Vitas, A. I., Arbillaga, L., De Peña, M. P., \& Cid, C. (2015). Coffee and spent coffee extracts protect against cell mutagens and inhibit growth of foodborne pathogen microorganisms. Journal of Functional Foods, 12, 365-374.

Monente, C., Ludwig, I. A., Irigoyen, A., De Peña, M. P., \& Cid, C. (2015). Assessment of total (free and bound) phenolic compounds in spent coffee extracts. Journal Agriculture and Food Chemisty, 63, 4327-4334.

Moustafa, H., Guizani, C., Dupont, C., Martin, V., Jeguirim, M., \& Dufresne, A. (2017). Utilization of torrefied coffee grounds as reinforcing agent to produce high-quality biodegradable PBAT composites for food packaging applications. ACS Sustainable Chemistry \& Engineering, 5, 1906-1916.

Page, J. C., Arruda, N. P., \& Freitas, S. P. (2017). Crude ethanolic extract from spent coffee grounds: Volatile and functional properties. Waste Management, 69, 463-469.

Panusa, A., Zuorro, A., Lavecchia, R., Marrosu, G., \& Petrucci, R. (2013). Recovery of natural antioxidants from spent coffee grounds. Journal of Agricultural and Food Chemistry, 61, 4162-4168.

Pettinato, M., Casazza, A. A., \& Perego, P. (2019). The role of heating step in microwaveassisted extraction of polyphenols from spent coffee grounds. Food and Bioproducts Processing, 114, 227-234.

Quiles, J. L., Farquharson, A. J., Simpson, D. K., Grant, I., \& Wahle, K. W. (2002). Olive oil phenolics: Effects on DNA oxidation and redox enzyme mRNA in prostate cells. British Journal of Nutrition, 88, 225-234.

Ramalakshmi, K., Rao, J. M., Takano-Ishikawa, Y., \& Goto, M. (2009). Bioactivities of low-grade green coffee and spent coffee in different in vitro model systems. Food Chemistry, 115, 79-85.

Sánchez-Carranza, J. N., Alvarez, L., Marquina-Bahena, S., Salas-Vidal, E., Cuevas, V., Jiménez, E. W., ... González-Maya, L. (2017). Phenolic compounds isolated from 
Caesalpinia coriaria induce S and G2/M phase cell cycle arrest differentially and trigger cell death by interfering with microtubule dynamics in cancer cell lines. Molecules, 22, E666.

Seidel, C., Schnekenburger, M., Dicato, M., \& Diederich, M. (2014). Antiproliferative and proapoptotic activities of 4-hydroxybenzoic acid-based inhibitors of histone deacetylases. Cancer Letter, 343, 134-146.

Shaidi, F. (2000). Antioxidants in food and food antioxidants. Nahrung, 44(3), S158-S163. Tirzitis, G., \& Bartosz, G. (2010). Determination of antiradical and antioxidant activity: Basic principles and new insights. Acta Biochimica Polonica, 57, 139-142.

Waldecker, M., Kautenburger, T., Daumann, H., Busch, C., \& Schrenk, D. (2008)

Inhibition of histone-deacetylase activity by short-chain fatty acids and some polyphenol metabolites formed in the colon. Journal of Nutritional Biochemistry, 19 , 587-593.
Wen, X., Takenaka, M., Murata, M., \& Homma, S. (2004). Antioxidative activity of a zincchelating substance in coffee. Bioscience Biotechnology and Biochemistry, 68, 2313-2318.

Woollard, D. C., \& Indyk, H. E. (2003). Tocopherols: Properties and determination. Encyclopedia of food sciences and nutrition (pp. 5789-5796). (2nd ed.). Academic Press.

Xu, J. G., Hu, Q. P., \& Liu, Y. (2012). Antioxidant and DNA-protective activities of chlorogenic acid isomers. Journal of Agricultural and Food Chemistry, 60, 11625-11630.

Yamagata, K., Izawa, Y., Onodera, D., \& Tagami, M. (2018). Chlorogenic acid regulates apoptosis and stem cell marker-related gene expression in A549 human lung cancer cells. Molecular and Cellular Biochemistry, 441, 9-19. 